DEUİFD Türk Kültürünü Mayalayanlar Özel Sayısı / 2021, ss. 45-72.

\title{
TÜRK KÜLTÜR MİRASINI MAYALAYANLARDAN YUNUS EMRE'DE DERVİŞLERİN, HAM SOFTA MÜDERRİS VE MOLLALARIN ELEŞTİRİSI*
}

Emrah DINDI**

\section{ÖZ}

Anadolu'nun İslamlaşması ve Türkleşmesinde, Yesevi öğretinin yayılmasında büyük etkileri olan Yunus Emre'nin dini düşünce sisteminin incelenmesi ve araştırılması kuşkusuz büyük önem arzetmektedir. Bu bakımdan, onun pek çok yönüyle ilgili bugüne kadar yüzlerce çalışma kaleme alınmıştır. Ne var ki dervişlerin; müftü, müderris ve mollaların kendilerini, iç dünyalarını kötülüklerden arındırmaksızın namaz, oruç, hac, zekât, kurban; tesbih, seccade, hırka, taç, zikir vb. salt zahiri düzeyde kalan şekilsel dindarlıklarının eleştirisine dair şimdiye kadar araştırdığımız kadarıyla, bir çalışma henüz yapılmamıştır. O bakımdan bu çalışmada, Yunus Emre'nin farklı nüsha ve baskılarından oluşan Risaletu'n-Nushiye'si ve Divan'ında iç dünyasını/gönlünü, arındırmamış, organlarını kötülüklerden alıkoymamış ve salt dinin kabuğunda, şeriat makamında yani şekilsel aşamada kalmış ham softaların ahlaki düşünce ve duruştan yoksun dindarlıklarının eleştirisi irdelenmiştir. Bu yönüyle araştırma, alana yeni katkilar sunan, otantik ve özgün bir çalışma özelliğindedir. Doküman analizi yönteminin kullanıldığı bu araştırma neticesinde, Yunus Emre tarafindan, dervişlerin ve zahir şeriat ehlinin özden yoksun, salt şekil ve görüntüde kalan dini tutum ve tavırlarının, din ve Tanrı anlayışlarının yerildiği görülmüştür.

Anahtar Kelimeler: Yunus Emre, Derviş, Ham Softa, Müderris, Molla, Eleştiri.

* Yazar; çalışmanın hazırlanması esnasında bilimsel ve etik ilkelere uyulduğunu ve yararlanılan tüm kaynakların kaynakçada belirtildiğini, çalışmanın maddi açıdan fonlanmadığını, çıkar çatışması bulunmadığını beyan etmektedir.

** Doç. Dr., Dokuz Eylül Üniversitesi İlahiyat Fakültesi Tefsir Anabilim Dalı, Assoc. Prof., Dokuz Eylül University, Faculty of Theology, Department of Tafsir, Izmir, Turkey, emrah.dindi@deu.edu.tr, ORCID ID: https:/ / orcid.org/ 0000-0002-66647590

Makalenin Hakemlere Gönderiliş Tarihi : 06/12/2021

Makalenin Hakemlerden Geliş Tarihi : 18/12/2021 


\section{CRITICISM OF DERVISHES, IMMATURE FANATICS, MUDARRIS AND MULLAHS IN YUNUS EMRE, WHO WAS ONE OF THE ESTABLISHERS OF TURKISH CULTURAL HERITAGE}

\section{ABSTRACT}

No doubt, it has great importance to examine and investigate the religious thought system of Yunus Emre, who had great impacts on the Islamization and Turkification of Anatolia and the spread of Yesevi School. In this respect, hundreds of studies have been conducted so far on many aspects of this. However, as far as we have reviewed so far, no study has yet been conducted on the criticism of the formal religiosity, which remains at a purely apparent level, for dervishes, muftis, mudarris', and mullahs' criticisms in terms of mere prayers, fasting, pilgrimage, zakat, sacrifices, rosary, prayer rugs, cardigans, crowns, dhikr, etc. without purifying themselves and their inner worlds of evil. In this context, in the present study, the moral thought of immature fanatics, who have not purified their inner worlds/hearts, did not keep their organs from evil, and remained in the shell of religion, in the mode of sharia, in other words, in the formal step, in the Risaletu'n-Nushiye and Divan of Yunus Emre that consisted of different copies and editions, and the criticism of the religiosity that lacked moral thought and stance was examined. In this respect, the study is an authentic and original one making new contributions to the literature. As a result of the study, in which the Document Analysis Method was used, it was found that the religious attitudes of dervishes and people of the apparent sharia, who lacked the essence and remained only in form and appearance, and their understanding of religion and God, were criticized by Yunus Emre.

Keywords: Yunus Emre, Dervish, Immature Fanatics, Mudarris, Mullah, Criticism.

\section{GİRİ̧̧}

Ortaçağın büyük Türk düşünürü sade Türk dervişi Yunus'un şiirlerinde, insanın kuşku ve şüphe içinde oluşu, dünya hayatı, ilahi aşk, vuslat, müşahede, mücahede, vahdet-i vücûd, vahdet-i şuhûd, her şeyin insanda dürülmüş olması, birlik ve dirlik, dünya ve insanın faniliği, ecel, ölüm, ölüm sonrası, kabir hayatı, cennet, cehennem, hesap, mizan, ahiret yaşamı, ömrü boşa geçirme, dört kapı kırk makam yani şeriat, tarikat, marifet ve hakikat makamları, insanın topraktan yaratılmas1, aslından kopması dünyaya gelişiyle yabancılaşması, kimseye hor bakmama, herkesi eşit görme, alçak gönüllü olma, gurur, kin ve kibirli olmama, öfkelenmeme, düşmanlık beslememe, biçim ve görüntüye aldanmama vb. dini, tasavvufi ahlaki konular ele alınmıştır. Anadolu'nun İslamlaşması ve 
Türkleşmesinde aynı şekilde Yesevi öğretinin yayılmasında büyük etkileri olan Horasanlı Türkmen Şeyhi Yunus Emre'nin dini düşünce sisteminin incelenmesi ve araştırılması kuşkusuz büyük önem arzetmektedir. Onun dini, tasavvufi, ahlaki, sosyal, kültürel, siyasi, tarihi, ilmi ve edebi kişiliğiyle ilgili bugüne kadar yüzlerce makale, onlarca kitap kaleme alınmıştır. Ne var ki dervişlerin, fakih, molla ve müderrislerin yani sofu ve şeriat bilginlerinin kendilerini, iç dünyalarını kötülüklerden arındırmaksızın namaz, oruç, hac, zekât, kurban; tesbih, seccade, hırka, taç, zikir vb. salt zahiri düzeyde kalan şekilsel dindarlıkların eleştirisine dair şimdiye kadar araştırdığımız kadarıyla, bu nitelikte bir çalışma henüz yapılmamıştır. Sadece Cemal Kurnaz'a ait Yunus Emre'de Tenkit adıyla yayınlanmış bir makalede, aynı şekilde İsmail Taş'a ait Yesevi ve Yunus'ta Sufi Eleștirisi adlı yayınlanmış bir bildiride genel ve öz olarak Yunus'un yönelttiği eleştirilere yer verilmiştir. Elbetteki bu çalışmaların alanyazına katkıları azımsanacak değildir. Dolayısıyla bu ürünlerden de faydalanılmıştır. Ancak Yunus'da şekil-öz, form-ahlak eleştirisinin yeni bir yaratım, yeni bir üslup, ifade ve bakış açısıyla ele alınması bu çalışmayı diğerlerinden farklı ve özgün kılmaktadır. O bakımdan bu çalışmada, Yunus Emre'nin farklı nüsha ve baskilarından oluşan Risaletu'n-Nushye'si ve Divan'ında iç dünyasını/gönlünü, kalbini, düşüncesini arındırmamış, organlarını kötülüklerden alıkoymamış ve salt dinin kabuğunda, şeriat makamında yani şekilsel aşamada kalmıs, ahlaki duyuş ve düşünceden yoksun dindarllğın eleştirisi irdelenmektedir. Literatür taraması yöntemiyle ele alacağımız bu araştırma, Yunus Emre'nin ahlaktan ve temel insanlık değerlerinden yoksun dindarlık eleştirisini, başka bir deyişle bağlı olduğu amaç, ülkü açısından içinde bulunduğu Müslüman/sufi toplumun ve zahir şeriat ehlinin davranışlarının, Tanrı ve din anlayışlarının eleştirisini ortaya koymaktadır. Bu yönüyle otantik ve özgün bir çalışma olduğunu düşünmekteyiz ve literatüre yeni katkılar sunacağını ümit etmekteyiz.

\section{Dervişlerin, Ham Softa Müderris ve Mollaların Eleştirisi}

Yunus'un şiirindeki yergiler büyük oranda ham sofuların, müderris, molla ve müftülerin bağnaz din ve Tanrı anlayışları üzerinde yoğunlaşır. $O$, dünyadaki eşitsizliğin, adaletsizliğin Tanrının taksimi olduğunu ileri süren kadıların, müderris, müftü ve mollaların bağnaz, kaderci din ve Tanrı anlayışlarını yargılamış, inceden inceye alaylı bir şiir diliyle bunlara başkaldırmıştır. Şöyle ki hem bazı kullarına atlar, avratlar, mallar, mülkler verecek hem de bazılarını bir pula muhtaç kılacak ve bu 
taksimatı da Rahim-ü Rahman olan Tanrı yapmış olacak, olur iş değil. Yine bir yandan dilediğini hidayete erdirenin kendisi olduğunu söylüyor olacak, öte yandan suçlunun kim olduğunu araştıracak ve azap edecek? Aynı şekilde hem her şeyi bilen, veren ve alan ve her şeyi yapan, ezelde levh-i mahfuza yazan da kişiyi azdıran da o olacak hem de tutup kişiyi sorgu suale çekip hesap sorup cevap bekleyecek. Hem ezelde kişiyi şakî/âsi eylemiş olacak, hem yaptı̆̆ her şeyi o yapmış olacak, nereye yönelirse o yöneltmiş olacak, içini heva, nefis ve şeytan gibi türlü ayıplarla donatmiş olacak hem de kişiye hesap sorup, onu suçlayıp cehennemde yakacak, olacak iş mi bu? Bu yargılamaları şöyledir:

Bir kuluna atlar virüp 'avret ü mâl çoklar virüp

Hem birinün yok bir pûlı rahm idici Rahmân benem ${ }^{1}$

Sen eyitdün iy pâdişâh Yehdi'l-lâhu limen yeşâ

Şerîkün yok senin i şâh suçlu kimdür 'azâb nedür

Levh üzere kimdür yazan azduran kimdür yâ azan

Bu işleri kimdür düzen bu su’âle cevâb nedür

Rahîm durur senün adun Rahîm'ligun bize didün

Mürşidlerün muştıladı Lâ taknetu hitâb nedür

$\mathrm{Bu}$ işleri sen bilürsin sen virürsin sen alursın

Ne kim dilersen kilursın yâ bu soru hisâb nedür

Biz umaruz mürvetünden cümle iş senün katundan

Senün o çok rahmetünden bu bir avuç türâb nedür

Kün'i bir kezin söyledün her nesneyi var eyledün

Yine âhir bir söz ile anı kılmak harâb nedür ${ }^{2}$

Sen ezelde beni 'âsî yazasın

Toldurasın 'âleme âvâzesin

1 Mustafa Tatçı, Yûnus Emre Dîvân (Ankara: T. C. Kültür ve Turizm Bakanlığ1 Kütüphaneler ve Yayımlar Genel Müdürlüğü, ts.),174.

2 Tatçı, Yûnus Emre Dîvân, 72-73. 
Her ne dilersen hakumda işledün

Ne tuşa durdumısa sen tuşladun

Ben mi düzdüm beni sen düzdün beni

Pür 'ayıb niçün yaratdun yâ Ganî

Gözüm açup gördügüm zindân içi

Nefs ü hevâ pür-tolu şeytân içiỉ

Yine bir yandan kıl gibi köprü yapacaksın öte yandan da geç de kevser şarabını iç diyeceksin kıl gibi köprüden (sırât) adam m1 geçer? Hem lütfun ile günahları örtüyor olacaksın hem de mahşer meydanında teraziler kurup günahları tartıyor olacaksın ve kişileri ateşe atmaya kastediyor olacaksın? Tanr1 bakkal m1 yahut pazarc1 $\mathrm{m} 1$ veya attar tüccar1 m1 ki teraziye ihtiyaç duysun? Kaldı ki günah O'nun huzurunda murdar şeylerin en murdarı, yaramaz şeylerin en yaramazı olduğu halde niçin murdarı açıp da bir daha tartsın? Hem bütün mahlûkatın Rabbi olacaksın hem de cehennem ateşinde ben hoş bir şekilde yanacağım sen de seyredeceksin öyle mi? Beni öldürüp gözüme toz toprak doldurdun geçmedi mi intikamın? Madem sonum bir avuç toprak ve cehennem ateşi o halde bunca kıyl-u kale ne gerek vardı Ey haşmet ve azamet sahibi? şeklinde tasavvuf anlayışı ile sevecen, bağışlayıcı ve koruyucu bir Tanrı sevgisine ulaşan, böyle bir Tanrı'ya inanan Yunus, kin, sorgu sual, ceza, cehennem, azap ve intikam gibi ulema tarafından bağnazlık ve katılıkla donatılan Tanrı tasavvurunu inceden inceye yermiştir. ${ }^{4}$

Kıl gibi köpri yaparsın geç diyü

Geçüben kevser şarâbın iç diyü

Kil gibi Sırât'dan Âdem mi geçer

Yâ üzilür yâ tayanur ya uçar

Yine fazlundur kulunı geçüren

Geçüben kevser şarâbın içüren

Terezü kurdun günâhum tartmaga

\footnotetext{
3 Tatç1, Yûnus Emre Dîvân, 340-341.

4 İlhan Başgöz, Yunus Emre (İzmir: Cumhuriyet Dünya Klasikleri, 1999), 107.
} 
Kasd idersin beni oda atmaga

Terâzû ana gerek bakkâl ola

Ya bazirgân tâcir ü 'attâr ola

Çün günâh murdârlarun murdârıdur

Hazretünde yaramazlar kârıdur

Pes niçün murdârı açup tartasın

Sen gerek lutfila anı örtesin

Sen basîrsin hod bilürsin hâlümi

Pes ne hâcet tartasın a'mâlümi

Haşali'l-lâh senden iy Rabbü'l-enâm

Sen temâşâ kılasin ben hoş yanam

Geçmedi mi intikâmun öldürüp

Çüridüp gözüme toprak toldurup

Bir avuç topraga bunca kıyl u kâl

Neye gerek iy Kerîm-i Zü'l-Celâl $1^{5}$

\subsection{Dervişlerin Eleştirisi}

Yunus Emre, madde ve meta/cennet, cehennem karşllı̆̆ında Tanrrya kulluğu eleştirdiği gibi derviş, fakih, müftü, müderris, hac1, hoca, kadıve mollalarda, beylerde, sultanlarda ve zamaninin halkında ideal kulluğa aykırı tutum ve tavırları da tenkit etmiştir. ${ }^{6}$ Her ne kadar kimi şiirlerinde dervişleri yere göğe kondurmasa, onlara hor bakan, onları incitenleri eleştirse $\mathrm{de}^{7}$ ve iyiden iyiye dervişleri idealize etse de medreseden sonra dâhil olduğu dervişler topluluğunun kötü hallerine tanık olmuş olmalı ki onları kınamaktan da çekinmemiş, dilde ve sözde dervişliğin aynı şekilde görüntü Müslümanlığının eleştirisini de ihmal

Tatçı, Yûnus Emre Dîvânı, 341-342.

6 Cemâl Kurnaz,. "Yunus Emre'de Tenkit". Türk Kültürü Araștırmalar, XXIX, 1-2, (1991), 260.

7 Tatçı, Yûnus Emre Dîvân, 304-306; Başgöz, Yunus Emre, 47-48. 
etmemiştir. Yunus'un şiirindeki yergi, büyük oranda ham sofuların bağnaz din ve Tanrı anlayışları üzerinde yoğunlaşır. Onun şiiri bu yanı ile çığır açıcı ve kalıcı olmuştur. ${ }^{8}$ Dolayısıyla dervişlerin derviş adına layık hareket etmediklerini, görüntü ve sûretlerinin başkalarını yanılttığını, zahir ve kabuklarının Tanrı eri görüntüsü verdiğini ancak özlerinin, tamamen riya, gösteriş, çıkar, iftihar ve övgü olduğunu, dilleri ile Şeyh'in (Çalab'ın) ululuğundan söz ettiklerini belirtmiştir. Bununla beraber yollarında şaşkın olduklarını, akıllarının karışı, tam tersine, nefislerinin ise güven ve asayiş içinde olduğunu, suretlerinin halka güldüğünü, yani halkı mutlu ettiğini ancak Hakka kulluklarının olmadığını, yaptıkları işlerin yanlış olduğunu, yürüyüşlerinin riya, gönüllerinin buğz, kin, kibir ve düşmanlık dolu olduğunu, aldatıcı derviş hırkalarının yani dini görüntülerinin suçlarını örttüğünü, hayatlarının tamamen ham olduğunu, türlü türlü suçlar işlediklerini dolayısıyla perdeler kalktığı gün işlerinin zor olacağını ifade etmiştir. Aşağıdaki dizelere bakıldığında kızım sana söylüyorum gelinim sen işit türünden Yunus'un kendi üzerinden ham softa dervişliği eleştirdiği, içinde yaşadığı dervişler topluluklarının eksikliklerini dile getirerek bir öz eleştiri yaptığı görülür. Daha önce de belirttiğim gibi dikkatleri üzerlerine çekmemek, baskılara maruz kalmamak için sufilerin, şairlerin ve ediplerin kullandığ 1 bir üslup idi aslında bu. Bu üslupta şair, sözde kendini eleştiriyor yahut kendine hitap ediyor ama gerçekte oklar toplumadır.

Ey bana derviş diyen, nem ola derviş benim

Ya bu adıma lâyık, hani elimde iş benim

Derviş derler adıma, bakarlar suratıma

Bilmezler ki dirliğim, külli sitayiş benim

Dil ile şeyhim ulu, yolda alûdan alû

Aklım evi kaygıll, nefsim asâyiş benim

Suretim güler halka, ya kani kulluk Hakka

$\mathrm{Bu}$ dirliğime bak a, hep işim yanlış benim

Kendi izimi bilirem, saluslanuben yürürem

8 Başgöz, Yunus Emre, 106. 
Buğz ü kibr ü adâvet, gönlümü almış benim

Suçumu örter hırkam, dirliğim cümlesi ham

Bir gün yırtılısar perdem, zehi düşvar iş benim

Derviş deye dolundum, ulu suçta bulundum

Yunus umduğum Haktan, rahmet imiş benim?

Yine Yunus amele, eyleme, davranışa yansimayan salt dilde, görüntüde kalan Hak sevgisinden de söz etmiştir. Sözde değil, özde ve eylemde görkemli ameller yapmak gerektiğini, dil ile şakımakla, çok maniler söylemekle, onu dövmek buna sövmek, vara yoğa öfkelenmek, kızmakla ve doğruya varmayınca dervişlik olunamayacağını ifade etmiştir. Bastığ1 yerde ot bitirmeyen, vardığ1 yerde derdi dindirmeyen öfkeyi; imansızlık, küfür ve dalalet olarak niteleyen Yunus, görüntüde/surette sakin, tesbihi elinde asa gibi, neredeyse çöpü incitmeyecek derecede öyle yola ayak basan, sakin ancak bir anda öfkesine kapılan, tesbihi kırıp imameyi yıkan, asayı kırıp kavga koparan, öfkenin kendilerini ele geçirip hükmettiği özünü İslamlaştıramamış kilıkta kıyafette, kisve ve kostümde kalan, kendilerini düzeltmeyi bırakıp başkalarını sınayan, yolda doğru gidenleri kınayan sofulardan da eleştirel bir dille söz etmiştir. Özünü doğrultamamış ancak surette sofu olanlara bu eleştirilerini şöyle dile getirmiştir:

Baksan bir kişiye suretâ sakin,

Ne sifat olduğunu ne bilirsin?

Boynunda tespihi elinde asa,

Çöp incinmeye, yola öyle basa

Bir bakarsın ansızın çıkagelir,

Tespih kırıp imame yıkagelir

Asayı kırıp koparır bir kavga,

Hiç yüzü yok ki bir kimseye baka

9 Burhan Toprak, Yunus Emre Divan (İstanbul: Odunpazarı Belediyesi Yayınları, 2006), 92; Tatç1, Yûnus Emre Dî̀âm, 184-185. 
Sual ettim: "Sofi bu ne hâldir?

Senin gibi kişiye bu muhaldir!”

Özür diledi ki: "Ben bir kişiyim,

Filan derler bana filan eşiyim.”

Bilirim onu itaati yoktur,

Halk içinde iyi sıfatı yoktur

Benim gibi kişiye hürmet etmez,

Cevap verir bana, öğüt işitmez

Ben ona vurdum, o yakamı tuttu,

Bana karşı gelip Hakk’1 unuttu

Ne diyeyim, ele geçirip onu,

Hükmetmiş hep ona öfke divan1 ${ }^{10}$

Yunus; şimdi sen dil ile, ben Hakkı severim deme

Ol padişah hazretine, görklü meta'iltmek gerek ${ }^{11}$

Sapmadan kişinin kendi özüne varması, özünü doğrultması önemlidir Yunus'un bu düşüncesinde. $O$ nedenle "Cümleler doğrudur sen doğruysan, Bulunmaz doğruluk sen eğriysen" sözleriyle her kişinin kisve ve kostümünü değil önce kendi özünü, esasını doğrultması gerektiğinden söz etmiştir. Herkese daim doğru sözlü ve doğru bakışlı olmayı önermiştir. Ona göre özünü doğrultanlar derinlerde yüzer, arş’ta ferş’te gezer hatta arş ve ferş bile bunlar için bir mahal değildir. Doğrular, dürüstler için daha ötelerde perde yoktur. Dürüstlük dirliği ebedidir. Doğrular, tecelliye ererler, ezel de ebed de onların nazarında birdir, iki âlem de (dünya ve ahiret) Tanri'ya vuslatta bir hicab/engel ve bir ateştir, bugün de yarın da dürüstler için birdir. Ne zahir/nesneler âlemi, görüntüler dünyası ne de batın idealar âlemi/cennet, Tanrı'ya varışta onlar için hicab değildir. Zahir neyse batın da odur onlar için. ${ }^{12}$

10 Yunus Emre, Nasihatler Kitabı (Risâletu'n-Nushiye) (Eskişehir: Türk Dünyası Kültür Başkenti Ajans1, 2013), 66-68.

11 Toprak, Yunus Emre Divan, 65.

12 Yunus Emre, Nasihatler Kitabı, 136-139. 
Dolayısıyla kişinin/dervişin 'Tanrı'dan nasip alabilmesi, eğriliği bırakması, doğru yola ermesi için, Çalab’’n taht kurup oturduğu gönlünü, içini öncelikle kibir ve kinden, her türlü pastan temizlemesi gerekir.

Sen derviş olamazsin ${ }^{13}$

Eğriliğin koyasın, doğru yola gelesin

Kibr ü kini çıkargıl, erden nasip alasın

Gönülde pas oturur, anda seni yitürür

İçeru şah oturur, girmezsin kim göresin ${ }^{14}$

Yunus Tanr1 evi ve hanesi olarak gördüğü insan gönlünün her tür öfke ve kinden temizlenmesi gerektiğini, öfke ve kinin Tanr1 yolunda engel olduğunu, içindeki kötü güçleri silip süpürmeden, özünü arındırmadan, duygularını kontrol etmeden, softanın savm-ü salat, hacc-1 zekâtının, elini yüzünü yıkamasının/abdest almasının ve rahleler kurup aşır/Kur'an okumasının fayda etmeyeceğini, Tanrının karargâhı olan içini kine, öfkeye kaptırdıktan, içi harap olduktan, lafı bol ortada işe yarar iyi bir işi olmadıktan, gizli sıfatını/özünü arıtmadıktan sonra dış duvarını, görüntüsünü riyayla örmesinin, sarık, seccade ve tesbihle süsleyip bezemesinin, bu zahiri, görüntüsel dış ibadetlerinin bir yararının olmayacağını dile getirmiştir. Tenin tertip ve tanziminin terkedilmesi, benlikten vazgeçilmesi gerektiği, insanın içini/gönlünü imar etmedikçe dışını/şeklini mamur eylemesinin bir faydasının olmayacağı, ${ }^{15}$ kişinin içi ve dışı murdar iken, dünya gözü aydın, gönül gözü kör ve uyur iken, gönlü karanlıkla dolmuş iken, yalan dava ve yanlış yol ile sureti, dini kostüm ve kisveyle nakşetmekle, dil ile dervişliğin/âşıklı̆̆ın olamayacağı yönünde sofuların ve şeriat bilginlerinin özden yoksun biçimci şekilci görüntü dindarlığına tenkitlerde bulunmuştur. O bakımdan Özçelik'in dediği gibi inandığı dini şekil olarak değil de muhteva olarak ele alması, onu dinin zahirine bakan dindarlardan ayıran en temel bir özellik olsa

\footnotetext{
Toprak, Yunus Emre Divan, 104-105.

Toprak, Yunus Emre Divan, 169.

15 İsmail Taş, 'Yesevi ve Yunus'ta Sufi Eleştirisi”, I. Ulusal Yunus Emre Sempozyymu, (Karaman: Karaman İl Kültür ve Turizm Müdürlüğü Kültür Yayınları, 2010), 281.
} 
gerektir. ${ }^{16}$ Yukarıda sözünü ettiğimiz bu tenkitler, aşağıdaki manzum ifadelerinde şöyle yer almıştır:

Evi süpürmedim, kim gelir bize?

Süpürgeci yok, kim gelip de düze?

Bunca ihmal edilmiş bu haneye,

Kim çağıra dostu: "Bize gel!" diye

Niçin geçmez acep yol bu aradan,

Öfke aldı yolu, bil her yöreden

Çok zamandan beri öfke yol almış,

Kimse izlememiş gizlide kalmış. ${ }^{17}$

Kurtarmaz elini yüzünü yuman,

Hak'tan korkmazsan boştur, aşr okuman

Değil öğüdüm, kusur bulmak için,

Sana bütün nasihatim, hak için

Riyayla örünce dış duvarını,

Hirsızlar aldı, içteki şarını

Dişıinda sarık, tespih ve seccade,

İçinde zünnâr bağlı, can belinde

Bezedin diş yüzünü, için harap,

Hiç kimse beğenmez, nedir sebep?

Böyle giderse hâlin nasıl olur?

Hiç iyi bir işin yok, lafin boldur

İşe yaramaz bu dış ibadetin,

Arı olmaz ise gizli sıfatın

Senin bâtın evini hırsız aldı,

16 Mustafa Özçelik, Biz̧im Yunus (Ankara: T.C Eskişehir Valiliği, 2010), 82.

17 Yunus Emre, Nasibatler Kitabı, 76. 
Şu zâhir amelin dişarda kaldı

Senin için şudur hepsinden evla,

Kulluğun gizli olmalıdır dostla ${ }^{18}$

Terk eylegil ten tertîbin gider senden benlik adın

İçün 'imâret olmadın taşundagı ma'mûr nedür ${ }^{19}$

İçün taşun murdâr iken 'işk n'eylesün senünile

Gönlün gözi uyur iken 'sssk n’eylesün senünile

Âşıklara yoldaş olup sâdıklara yâr olmadun

Ölmezdin öndin ölmedün ‘'şk n’eylesün senünile

Dünyâ gözün rûşen idüp gönül gözün kör eyledün

Zulmet tolıcak gönlüne ‘sşk n’eylesün senünile

Bize girçek dervîş gerek cihân toldı da'vâ ile

Yalan da'vâ iderisen 'işk n'eylesün senünile

Dervisşligi sanma hemân sûret düzmegile olur

Dilde ise senün işün ‘'şk n'eylesün senünile ${ }^{20}$

Yine Yunus sofuların özden, dinin ruhundan, evrensel ahlaki edimlerden yoksun görüntü dindarlığını eleştirmeye devam ediyor. Bu sofuların halk arasında ellerinden tespihlerini, dillerinden marifeti düşürmediklerini ancak gönüllerinin aymaz olduğunu, ne tesbihi ne marifeti kabul etmediklerini, riya ile kulluk ve taatte bulunduklarını, maksatlarının başka şeyler olduğunu, dillerinde zikirlerinin çok ancak sabırlarının yok olduğunu, ağızlarından çıkan ve kulaklarının işittiği zikirleri maalesef kalplerinin, iç dünyalarının asla işitmediğini, görenlerin başlarındaki taca, üzerlerindeki hırkalara bakıp ellerine kapandıklarını, şekle aldanıp zerrece günah işlemediklerini zannettiklerini gözler önüne sermiştir. Benzer şekilde bu dervişlerin/sofuların ibadet ve taatlerinin

\footnotetext{
18 Yunus Emre, Nasihatler Kitabı, 71-72.

19 Tatçı, Yûnus Emre Dîvân, 46.

20 Tatçı, Yûnus Emre Dîvânı, 46.
} 
taçta yani dilde ve dış görüntüde olduğunu, iç pazarlarının boş ve kof olduğunu, bunların ettiğini dinden dönenlerin bile etmediğini, görenlerin sofu sandıklarını, selam verip sayg1 duyup kendilerinden çekindiklerini, marifetten söz ederken bile riyakârca davrandıklarını, gönüllerinin büyüklenme, kibir ile dolu olduğunu deşifre etmiştir. Dolayısıyla tarikat ehlinin riyasina bir reaksiyon olarak meydana gelen, hususi giyim, tekke, zikir vb. şeylerle halktan ayrilmayı kabul etmeyen hatta yaptıkları kötülükleri aşikârca yapan ancak iyiliklerini gizleyen dolayısıyla da halkın kınamasına maruz kalan ve bu yüzden Melâmeti diye isimlendirilen Horasanîlerin Anadolu'daki uzantısı olan ${ }^{21}$ Türk düşünürü Yunus Emre, dönemin dindarlık anlayışını iğneleyici bir üslup ile eleştirerek dervişliğin görüntü ve şekille, cübbe ve sarıkla, hırka ve taç ile olmayacağını, gönlünü derviş eyleyenin şekle hırkaya muhtaç olmayacağını, dışını değil içini derviş eylemeyi dile getirmeyi ihmal etmemiştir. Benzer şekilde Yunus, şeyhlik adını takınıp da taati bir tarafa bırakmış olan, adları şöhret olmuş, ancak cümle taatleri suç olan, kerametim var diye halka caka satan, gösteriş/riya yapan şeyhleri de "nefsini Müslüman etsin var ise kerameti" diyerek, bunları, daha kendi benlerini, özlerini dahi Müslüman edememiş olmakla eleştirmiştir. İşte Yunus 13. yüzyıl sufiliğin yahut müslümanlığın bu portresini aşağıdaki dizeleriyle ortaya koyuyor:

Sofuyum halk içinde tesbih elimden gitmez

Dilim marifet söyler, gönlüm hiç kabul etmez

Boynumda icâzetim, riya ile tâatim

Endişem ayruk yerde, gözüm yolum gözetmez

Hoş dervişem sabrım yok, dilimde ezkârım çok

Kulağımdan gireni, hergiz içim işitmez

Görenler elim öper, tac ü hırkama bakar

Şöylece sanırlar beni, zerrece günah etmez

Taşımda ibadetim, sohbetim hoş tâatim

İç pazara gelince, bin yıllık ayyar etmez

21 Abdulbaki Gölpınarlı, Yunus Emre Hayatı, Sanatı ve Şïrleri (İstanbul: Varlık Yayınevi, 1975), 4. 
Dışım derviş, içim boş, dilim tatlı, sözüm hoş

İllâ ben ettiğimi, dinin denşüren etmez

Görenler sofu sanır, selâm verir utanır

Anca iş koparaydım, el erüben güç yetmez

Söylersem marifeti saluslanırım kati

Miskinliğe dönmeğe, gönlümden kibir gitmez

Yunus eksikliğini Çalabına arzeyle

Anın keremi çoktur, sen ettiğin ol etmez ${ }^{22}$

Dervişlik didükleri hırkayıla tâc degül

Gönlin dervîş eyleyen hırkaya muhtâc degül

Hırkanun ne suçı var sen yolına varmazsan

Varg1l yolınca yüri er yolı kalmaç degül ${ }^{23}$

Miskîn Yûnus dir çagırur 'âşıkıyam miskînlerün

Dervîş degülise taşum içümi dervîş eyleyem ${ }^{24}$

Takındım şeyhlik adın kodum ma'şuk tâatın

Verdim nefsin muradın kani Hakk ile pazar

Yayıldı Yunus adı suçtur cümle tâatı

Çalab'ım inâyeti suçun geçire meğer ${ }^{25}$

Kerâmetüm var diyen halka sâlûslık satan

Nefsin müsülmân itsün varısa kerâmetii ${ }^{26}$

22 Toprak, Yunus Emre Divam, 106; Tatçı, Yûnus Emre Dîvâm, 92.

23 Tatçı, Yûnus Emre Dî̀âm, 129.

24 Tatçı, Yûnus Emre Dî̀ân, 161.

25 Abdulbaki Gölpınarlı, Yunus Emre Hayatı ve Bütün Şïrleri (İstanbul: Türkiye İşbankası Kültür Yayınları, 2006), CCXLIV.

26 Tatç1, Yûnus Emre Dîvâm, 311. 
Ulu Bilge Yunus döneminin dervişlerinde ahlaki çöküntüyü öz eleştirel bir üslupla dile getirmeye devam ediyor. Dervişlerin derviş geçinenlerin, ellerine geçinceye dek haram yemediklerini, ancak ellerine geçince affetmediklerini, dillerinin Kur'an, tefsir, hadis, fikıh vb. zahiri ilimlerle ancak gönüllerinin dünya sevgisiyle dolu olduğunu, diş görüntülerinin iyi ad, nam ve şöhrette fakat gönüllerinin fasit taatte olduğunu, bu türden içi dışı bir olmayan ikiyüzlü aldatıcı insanların nerede ise bulunmadığını, dışları tanıdık, içleri yabancı, dilleri hoş ancak gönülleri mürted olan, işleri kötü olduğu halde adlarının/namlarının iyi olduğunu dolayısıyla böyle fitnenin bulunmadığını, dışlarının parlak ne var ki içlerinin ham, ahlaki olarak bir adım ileri gitmedikleri halde Tanrı'dan haber vermeye kalkıştıkları, hırkalarının yani derviş görüntülerinin suçlarını örttügünü, gönüllerinin başka pazarlarda, dinlerinin ise maalesef dillerinde olduğunu açık yüreklilikle dile getirmiştir. Şeyler, pirler, dervişler ve ulema geldiğinde halkın hep ayakta durup onlara sayg1 hürmet gösterdiklerini, bunların ise kendi çıar ve menfaatleri için başköşeye geçip kalın döşeğe, düz yere çöktüklerini, riyakârlık, hilekârlık ve düzenbazlıkla ele geçirdikleri bu firsatlardan dolayı artık maşuktan ayrı kalmış olma derdinin işlerine yaramadığını gözler önüne sermiştir. Bu eleştirileri onun şiirlerinde şöyle yer etmiştir:

Ben dervişim diyenler haramı yemeyenler

Haramın yenmediği ele girince imiş ${ }^{27}$

Benüm gibi mücrim kul gel iste bir dahı bul

Dilümde ilm ü usûl gönlüm de dünyâ sever

Zâhirüm eyü adda gönlüm fâsid tâ‘atda

Bulunmaya Bagdâd'da bencileyin bir 'ayyâr

Taşum biliş içüm yâd dilüm hoş gönlüm mürted

Yavuz işe eyü ad böyle fitne kanda var

Taşum göyner içüm ham dirligüm budur müdâm

Yol varmadum bir kadem 'Arş'dan virürem haber

Hırkam suçuma perde endîşem fâsid yirde

27 Gölpınarlı, Yunus Emre Hayatı ve Bütün Şïrleri, Önsöz. 
Gönlüm ayruk bâzârda dilümde sözüm esrâr ${ }^{28}$

Halk hep ayağa durur ben seğirttim oturdum

Geçtim sadır yerine döşek kalın yerim düz,

Bunun gibi sâlûsluk çünkim elime girdi

Artık n'işîme yarar derd ü firak âh u sûz ${ }^{29}$

\subsection{Müderris ve Mollaların Eleştirisi}

Yunus Emre'nin tümden yergiye ve kınamaya ayrılmış şiirlerinin sayısı azdır. Bunların bir kısmında yergi bize Dede Korkut'taki ozanı hatırlatır. Geneldir, belli kişilere ve sınıflara yönelmez. Belli bir zamana ve insan çevresine oturmaz. Somut insanları ve olayları bize vermez. Ama Yunus Ozan gibi dolaylı da konuşmaz, söyleyeceklerini açıktan dobra dobra söyler. Kimi şiirlerinde ise bu yergi yerele, özele ve somuta iner. ${ }^{30}$ $\mathrm{Bu}$ özel yergilerinde Yunus, döneminde toplumun her tabakasinda görülen ahlaki yozlaşmadan özellikle de müderris, âlim ve hocalardan hatta beylerden de yakınmaktadır. Yapmış olduğu eleștirilerinde bu sınıf için şïrlerinde genelde cahil, zahit, hoca, danışman, münkir, münafik, şeriat oğlanı ve leş kuzgunu gibi isimler kullanılmıştır. Dolayısıyla kendini bilmek ve yenmek isteyen dervişlerin yolunun hacının, hocanın, şeriat bilginlerinin daha doğrusu bilgin geçinenlerin yani danışmanların (danişmentlerin) yolu olmadığını ifade etmiştir. ${ }^{31}$ Adam gibi Müslümanın nadir olduğundan, şeriat âlimlerinin medresede okuduklarını tutmadıklarından, pek çok bina ve irab gibi zahir ilimleri okuduklarından ancak havfu reca/Tanrı korkularının olmadığından, Kur'an'a kulak verilmediğinden, dervişlerin kendi yollarını gözetmediklerinden, halkın öğüt işitmediğinden, beylerin mürüvvetinin kaybolduğundan, yediklerinin yoksul eti, içtiklerinin kan, er gelmiş er gidecek olmaları gerekirken, erlikten el etek çekmiş olduklarından, şerden neredeyse Deccâl'ın ortaya çıkacağından, helal ve haramın birbirine karıştığından sızlanıp yakınmıştır. Aynı şekilde zamane Müslümanlarının kötü halde

\footnotetext{
Tatç1, Yûnus Emre Dîvâm, 33-34.

29 Tatçı, Yûnus Emre Dîvâm, 84; Gölpınarlı, Yunus Emre Hayatı ve Bütün Şïrleri, Önsöz.

30 Başgöz, Yunus Emre, 105.

31 Sabahattin Eyuboğlu, Yunus Emre (İstanbul: Cem Yayınevi, 1971), 49, 51.
} 
olduğundan, helal lokma yerine haramın kıymetli olduğundan, haram ile hamîrin/içkinin yaygınlaştı̆̆ından, fesat işler yapanların saygıyla anıldıklarından, fakirlerin miskinlikten ellerini çektiklerinden, peygamber yerine geçen hocaların halkın başına zahmet ve dert olduklarından söz etmiş, bu nedenle de dönemi ahir zaman olarak görmek durumunda kalmıştır. O, ikiyüzlüleri, gösteriş olsun diye ibadet edip ardından günah işleyenleri, halka müslümanlık tasladığı halde gönül kıran, menfaatine düşkün olan ve şöhret peşinde koşan, İslam'ın deruni manasından yoksun olan, gayeleri şekil ve gösteriş olan şeriat oğlanlarını, müderris, müftü ve mollaları daha doğrusu hocaları kınamıs, bunlardan ac1 ac1 şikayet etmiştir..$^{32}$ Talat Halman'ın dediği gibi böyle çarpıc1 protestolar, dünya şiirinde bile az rastlanır güçtedir. Denilebilir ki yalnızca Yunus'un yaşadığ Orta Çă̆’da değil, 19. yüzyıldan önce herhangi bir ülkenin har hangi bir döneminde, adaletsizliğe ve sömürüye böyle başkaldırmış pek az şair olmuştur. ${ }^{33} \mathrm{Bu}$ sızlanma ve yakınmalar, onun dizelerinde şöyle yer etmiştir:

İşidün iy ulular âhir zamân olısar

Sag müsülmân seyrekdür ol da gümân olısar

Dânişmend okur dutmaz derviş yolın gözetmez

Bu halk ögüt işitmez ne sarp zamân olısar

Gitdi begler mürveti binmişler birer atı

Yidügi yohsul eti içdügi kan olısar

Ya'ni er gelmiş erden elini çekmiş şerden

Deccâl kopısar yirden âhir zamân olısar

Aceb mahlûk irişdi göz yumuban dürişdi

Helâl harâm karışdı assı-ziyân olısar ${ }^{34}$

Müsülmânlar zamâne yatlu oldı

Helâl yinmez harâm kiymetlü oldı

32 İbrahim Agâh Çubukçu, "Yunus Emre ve din felsefesi", Ankara Üniversitesi İlabiyat Fakültesi Dergisi XIX (1973), 11.

33 Talat Halman, A'dan Z'ye Yunus Emre (İstanbul: Yap1 Kredi Yayınlar1, 2003), 28.

34 Tatçı, Yânus Emre Dîvâmı, 49; Gölpınarlı, Yunus Emre Hayatı ve Bütün Şïrleri, Önsöz. 
Okınan Kur'ân'a kulak tutulmaz

Şeytânlar semirdi kuvvetlü old1

Harâm ile hamîr tutdı cihânı

Fesâd işler iden hürmetlü oldı

Fakîrler miskînlikden çekdi elin

Gönüller yıkuban heybetlü oldı

Peygamber yirine geçen hocalar

Bu halkun başına zahmetlü oldı ${ }^{35}$

Türk-İslam mutasavvıfi Yunus felsefesinde şekil, biçim ve görüntü yanıltıcı ve yalancıdır, dolayısıyla aldanılmaması gerekir. Yetmiş iki millet bir görülmeli, hor, hakir, aciz, fakir miskin olanlar er görülmeli yani diğerine denk görülmelidir. Toplumda basit, bayağ1 aba giyenlerin değersiz aşağı görülmemesi gerektiği gibi, parlak, yaldızlı elbise giyenlerin, makam, mevki, riyaset ve dava sahiplerinin de üstün görülmemesi gerekir. Çünkü Hz. İsa gibi dünyayı terkeden nicelerinin Tanrının katında fevka'l-ulâ'ya yani en yüce mertebelere çıktıklarını, Karun gibi nice şaşaalı, yaldızlı parlak elbise giyen dünyayı kovuşturan makam, mevki sahiplerinin ise toprak altına indirildiklerini ifade etmiştir. Aba yahut atlas giyenlerin, medreselerde zahiri ilimleri okuyanların görüntülerinin aldatmaması gerektiğini; namaz, oruç, hac, zekât, kurban vb. şeriatın şekli ritüellerini yerine getirenlerin görüntüsel taat ve ibadetleriyle başkalarına ta'n etmemeleri, mağrur olmamaları gerektiğini, mağrur olanların merdut olabileceğini çünkü şeriata göre merdut olan kefen soyucunun Hak katında makbul olduğunu, yine şekil, suret, biçimde küfür donunu giymiş nicelerinin gerçekte canları içinde gönüllerinin imanla dolu olduğunu, dolayısıyla görüntüye aldanılmaması gerektiğini dile getirmiştir. Yunus'un aşağıdaki dizelerinde gördügümüz bu ifadelerinde, insanın özünü, kalbini, canını, ruhunu, zihnini ve eylemlerini kötülüklerden tezkiye ve tasfiye etmeyi amaçlayan tekke din anlayışı karşısında dışını dinin formel ödevleriyle, atlas libasla süsleyen şeriat ehlinin ve medrese ulemasının gurura kapılmalarına dolaylı olarak bir eleştiri söz konusudur.

35 Tatç1, Yûnus Emre Dîvân, 316-317. 
Kamusun bir gör, kemterin er gör

Alu görmegil pelâs giyeni

Tez ç1karırlar fevkal'ulâya

Bin İsa gibi dünya yakanı

Tez indirirler tahtesserâya

Bir Karun gibi dünya kovanı

Âşık olanın nişanı vardır

Melâmet olur belli beyanı

Zühdüm var deyu ta'n eylemegil

Merdut ederler mağrur olanı

İlmim var deyu mağrur olmagil

Hak kabul etti kefen soyan1 ${ }^{36}$

Egerçi küfr tonını geydi sûret

Gönül cânı görür îmân içinde ${ }^{37}$

Dînin terk idenün küfürdür işi

Bu ne küfürdür îmândan içerü ${ }^{38}$

Yine bazı riyaset, makam, mevki ve dâva sahibi olan ve zahiri ilimlerde kâmil geçinen dünya leşi kuzgunlarının ehl-i tariki inkâr hallerini, gözde hor ve hakir görülen, fakir ve miskin gezen âriflerin kemallerini beyan eden Yunus'un "Bir sinek bir kartal sallade vurdu yere/Yalan değil gerçektir ben de gördüm to₹unu” beyti de şeklin, görüntünün yanıltıcı ve aldatıcı olduğunu beyan eder. Niyâzî Misrî̀nin (ö. 1105/1694) yorumunda geçtiği gibi bu beyit, ariflerin, âşıkların zâhirlerinin/dış görüntülerinin fakr ü fenasını ve tezellül ü meskenetlerini görüp istihza tariki ile onlara bazı sualler eylediklerini, gözlerine sinek kadar görünmeyen âriflerle söze ve irfana geldiklerinde sinek misali olan bu fakirin/ârifin, şahin gibi ol kartalı kaldırıp yere vurduğunu beyan eder.

36 Toprak, Yunus Emre Divanı, 177; Tatç1, Yûnus Emre Dîvâm, 278.

37 Tatç1, Yûnus Emre Dîvân, 278.

38 Tatç1, Yûnus Emre Dîvân, 234. 
Yani gözde ve görüntüde hor olan derviş azamet ve şöhret sahibi olan filân efendiye/abid, zahit ve âlimlere galip olup onu sindirmiştir. Kartal her ne kadar gözde büyük ise de yediği leștir ve kendinden çıkan dahi cifedir. Ama arı her ne kadar gözde küçük ise de yediği güzel kokulu çiçeklerdir, kendinden çıkan dahi güzel lezzetli baldır. Dolayısıyla görüntüde/zahirde arı, küçük, zayıf ve çelimsiz görülse de hakikatte kartaldan daha değerli ve daha güçlüdür. ${ }^{39}$ Yunus, gökten inen dört kitab1 günde bin kez okusalar da eğer erenleri, âşıkları yadsıyor, inkâr ediyor, telin ve tekfir ediyor iseler gerçekte onlar Hak'tan uzaktırlar diyerek o dönemde zahir şeriat ehli tarafından ariflerin ve erenlerin yadsındığına işaret etmiştir.

Gökden inen dört kitâbı günde bin kez okurısan

Erenlere münkirisen dîdâr ırak senden yana

Miskîn Yûnus erenlere tekebbür olma toprak ol

Toprakda biter küllîsi gülistânı toprak bana ${ }^{40}$

Usul esas, yol, yöntem vb. açılardan medreselilerle marifet ehlinin yol ve yöntemlerine temas ederek dolaylı yönden medreseye eleştiride bulunmuştur. Söz gelimi şeriat makamında evliya olanın hakikat makamındaki ideal kulluk yaşamına göre gerçekte inkârcı (kâfir) yani nankör olduğunu, kendilerinin medreselerde okutulan zahiri şeriat ilimleri değil, marifet/hakikat ilmi talipleri olduklarını, ilim için okudukları kitabın, şeriat kitabı değil aşk kitabı, medreselerinin ise aşk medresesi/Çalap okulu olduğunu, müderrislerinin ise medreselerde biçimsel ilimleri okutan müderrisler değil Çalap Taala olduğunu ifade etmiştir. Tekkelerde taliplerin kendi ilahi aşk kitapları yerine medreselerde okutulan zahiri din ilimlerinin gerçekte kişinin kendi gözlerine perde olduğunu, aslında bu ilimlerin dünya ve ahiret hesabı için okunduğunu, bunları okuyanların ilahi aşktan fakir ve yoksun olduklarını, Dost'a vuslata bir katkılarının olmadığını "bu okunan varak nedir?" diyerek tenkit etmiştir. Ona göre zahiri ilmü amellerin, şekilsel zühd-ü taat ve ibadetlerin aşksız yani Tanrısal sevgi ve muhabbet olmadan değeri yoktur

39 Toprak, Yunus Emre Divan, 189.

40 Tatçı, Yûnus Emre Dîvânı, 11. 
daha doğrusu ona göre helal de değildir. Aynı şekilde Yunus, medreselerde çok kitap okuyan zahir şeriat ehlinin/ulemay1 rüsumun kendilerinde/sûfilerde özür, kusur aradıklarını, ancak kendilerinin aşk varakından okumadıklarını dolayısıyla ilahi sırrı bir türlü ayan beyan bilmediklerini, okudukları zahir ilimle de amel etmediklerini, batın/gönül gözünü açıp âşıkla maşukun halini bilmediklerini, maalesef hali kâlden ayırt edemediklerini, Hakka vuslat ve varmada fakihliğin fakihlere bir tuzak olduğunu belirtmiştir. Yunus müftü ve müderrislerin, fakihlerin ilahi aşktan/Tanrısal sevgiden yoksun olduklarını, şayet aşk şarabından, ilahi aşk sohbet ve sözünden nasiplenmiş olsalar bunların mat olacaklarını, ilahi devleti bulup baki olacaklarını, hırka, takke ve cübbe ile âlim olunamayacağını, medreselerde bunca varak kitap okumakla din ve diyanetin olmayacağını, amel etmedikten sonra yedi mushafı yüz bin defa da okusa bir kazancının olmayacağını, bin kez hacca varsa, bin kez gaza etse ve bu uğurda yüz y1l yol kat etse de hatta müderris ve fakih olsa da bir kez gönül yıktı, insanı kırdı ise gerekse varıp yüz yıl okusa da bunların bir faydasının olmayacağını israrla vurgulamaktan geri durmamıştır. Çünkü O’na göre gönül, Halil İbrahim'in taştan, tuğladan yapmıs olduğu sûrî Kâbe'den daha üstündür. Çünkü gönül Hakk'ın durağı, mekânı ve karargâhıdır. O bakımdan Yunus, Öztelli'nin de belirttiği gibi gönül kırmamanın yahut gönül almanın şekilsel dini ödevlerden daha üstün nitelikler olduğunu telkin etmeye çalışmıştır. ${ }^{41}$ Yine Yunus dinin ve imanın aslı olan doğruluk ve gerçeklik olmadan fakihlerin din çattıklarını, gökten inen Allah'ın Kitab'indan haber vermek yerine başka kitaplardan öttüklerini, niçe tasnif edilmiş kitaplar okuduklarını, nice bina-u irap/cümle çözümlemeleri yaptıklarını, ancak kendilerinde havf-u reca/Tanrı korkusu, bilinci olmadığını, zahiri ilimleri okuduklarını ancak kendi özlerini bilmediklerini, ibret almadıklarını, Mustafa'nın hadislerini şerh ile söz sattıklarını, riyalı namazlarının çok, hayırlarının az olduğunu, halka fetva verdiklerini ne var ki bu fetvaları kendilerinin tutmadıkların, okudukları ilimle amel etmediklerini, günahlara daldıklarını, samimiyet ve ihlastan yoksun olduklarını dile getirmiştir. Yunus'un bu beyitlerinde o dönem Anadolu'da medresenin ve müderrislerin, zahiri ulemanın öncülük ettiği zahirde, şekil ve görüntüde kalan, Tanrı bilinci ve sorumluluğu oluşturmayan ahlaktan yoksun din anlayışına aslında bir

41 Cahit Öztelli, Yunus Emre Yaşamı ve Bütün Şïrleri (İstanbul: Özgür Yayın Dağıtım, 1992), 56. 
eleştiri vardır. Kısaca Köprülü'nün de belirttiği gibi Yunus vb. şâirmutasavvıflar yalnız ulemayı rüsum için değil zahiri ilimlere karşı da kayıtsız ve istihfafkâr davranmışlardır. ${ }^{42}$ Yukarıda sözünü ettiğimiz bu eleştiriler, Yunus'un aşağıdaki dizelerinde şöyle yer almıştır:

Bundan içeri haber işit, edeyin ey yâr

Hakikatin kâfiri, şer'in evliyasıdır

Biz talib-ilmiz, aşk kitabın okuruz

Çalap müderris bize, aşk hot medresesidir

Evliya safa nazar ideli günden beru

Hâsıl oldu Yunus'a her ne kim olasıdır ${ }^{43}$

Vuslat eri oldun ise, göz hicabın bildin ise

Dostu ayân gördün ise, bu varlığı bırak, nedir

İlim hot göz hicabıdır, dünya âhiret hesabıdır

Kitap hot aşk kitabıdır, bu okunan verak nedirr ${ }^{44}$

İlm-ü hikmet okuyanlar, âşıklıktan fakir-dürür bunlar

Mansur oldum asin beni, hep dillerde söyleneyim ${ }^{45}$

Miskîn Yûnus zehr-i kâtil 'ş̧k elinden tiryâk olur

'İlm ü 'amel zühd ü tâ'at pes 'işksuz helâl olmaya ${ }^{46}$

İy çok kitâblar okıyan sen kim dutarsın bana dak

Tâ bilesin sırrı 'iyân gel '1şkdan okı bir varak

Okımagıl ilmün yüzin ilme 'amel eyle güzin

Aç gönülden bâtın gözin ‘âşık-ma'şûk hâline bak

\footnotetext{
Fuad Köprülü, Türk Edebiyati'nda İlk Mutasavvflar (Ankara: Türk Tarih Kurumu Basımevi, 1976), 321, Dipnot 36.

43 Toprak, Yunus Emre Divan, 91; Tatç1, Yûnus Emre Dîân, 25.

44 Toprak, Yunus Emre Divanı, 107; Tatçı, Yûnus Emre Dî̀ân, 31.

45 Toprak, Yunus Emre Divan, 126.

46 Tatçı, Yûnus Emre Dîvânı, 7.
} 
Gör ma'şûkun ne işdedür 'âşık dahı ol işdedür

İkisi bir sır işdedür iki sanup kalma rrak

İkilikden geçemedün hâli kâlden seçemedün

Hak'dan yana uçamadun fakîlık oldı sana fak ${ }^{47}$

Toldur kadeh sungıl bize 'işk şarâbından iy sâkî

Ol badyadan gerek bize andan içe şeyh ü fakî

Sohbetümüz ilâhîdür sözümüz kevser âbıdur

Şâhumuz şâhlar şâhıdur çalgumuzdur dost firâkı

Kim ki bir dem sohbet ola müftî müderris mât ola

Bir İlâhî devlet ola andan içen oldı bâkî

Hırka vü takye yol virmez ferecile âlim olmaz

Dîn diyânet olmayıcak n'eylersün bunca varak1

Okıdun yidi mushafı tâ‘at gösterürsün sâfî

Çünki 'amel eylemedün gerekse var yüz bin okı

Bin kez hacca vardunısa bin kez gazâ kıldunısa

Bir kez gönül sıdunısa gerekse yüz yıl yol dok1

Gönül mi yig Ka'be mi yig eyit bana 'aklı iren

Gönül yigdür zîrâ ki Hak gönülde tutar turak1 ${ }^{48}$

Şeyh ü dânişmend ü fakı gönül yapan bulur Hak’1

Sen bir gönül y1kdunısa gerekse var yüz yıl ok1 ${ }^{49}$

Dîn ü îmân bünyâdı togrulıkla gerçeklik

Ol tamâm olmayıcak neyile dîn çatarsın

Çün Kur'ân gökden indi anı Allâh buyurdı

Andan haber virsene hâ kitâbdan ötersin

47 Tatç1, Yûnus Emre Dîvân, 102.

48 Tatçı, Yûnus Emre Dîvâm, 298.

49 Tatçı, Yûnus Emre Dîvân, 334. 
Okursin tasnîf kitâb niçe binâ vü i'râb

Havf ü recâ sende yok eyle ki bir Tatar'sın

İlm okımak bilmeklik kendözini bilmekdür

Pes kendözün bilmezsen bir hayvândan betersin

İlm okımak ma'nîsi 'ibret anlamagiçün

Çün 'ibretden degülsin görmedin taş atarsın

On iki bin hadîsi cem` eyledi Mustafâ

Anı işitdün meger şerh ile söz satarsın

Kılursin riyâ namâz yazugun çok hayrun az

Dinle neye varur söz Cehennem'de yatarsın

Halkı fetvâ virürsin yâ sen niçün dutmazsın

İlmün var 'amelün yok hâ günâha batarsın

Sen fakîhsün ben fakîr sana tanumuz yokdur

İhlâsıla gelürsen bizden nesne ütersin ${ }^{50}$

Yunus Emre Tefsir, Hadis, Fıkıh, Kelam vb. zahiri ilimlerle uğraşan medrese ehline yönelik eleştirilere devam etmektedir. Bunların o kadar çok metinleri şerh ile uğraşmalarına rağmen Hakikat'ın manasını bilmediklerini, erenlerin/Hakikat ehlinin aksine zahir/şeriat ehlinin, ulemayı rüsumun bu ilimlerle uğraşılarında riyâ içinde olduklarını, Hakikat'in bir deniz şeriatın ise gemi olduğunu, ne yazık ki zahir şeriat ehlinin/ulemayı rüsumun bir türlü gemiden inip de Hakikat denizine dalmadıklarını, dinin şekilsel ritüeller makamı olan şeriat eşiğinde kaldıklarını, içeri girip de ne var ne yok bilmediklerini, Hakikat erenlerinin tersine bu şeriat ehlinin cedel, tartışma, iddia ehli olduklarını, dört kitabı şerhetseler de Hakikat'te asi, günahkâr olduklarını, çünkü tefsir okuduklarını ancak manayı/hakikati bilmediklerini dile getirmiştir. Bu yüzden Faruk Kadri Timurtaş'ın dediği gibi Yunus'a göre Hakka, hakikate, mutlak varlığa ve gerçeğe zahiri ilimlerle değil irfan ve aşk ile

50 Tatçı, Yûnus Emre Dîvân, 202. 
erişilir. ${ }^{51}$ Büyük bir olasılıkla ona alfabeyi/elif bayı öğretmeye çalışmaları onun bir türlü buna dilinin dönmemesini ifade eden şiirleri ve yine "Zâhir-i hâlde okumă̆a dili varmayıb, hâme gibi hurûf-ı teheccînin edâsinda kâsir olduğg" yönünde Şekâyik tercümesinde ve yine "Okumak kasdettiği hâlde, burûf-i teheccîyi ikmâle dili dönmediğ̌" ${ }^{52}$ yönünde Âş1k Çelebî'de geçen ifadeler de aslında ilmi Hakikat, ilmi batın, ilmi irfan ve ilmi işaret değil de medreselerde okutulan ilm-i ibare, zahir şeriat ilimleriyle Tanrrya ulaşılamayacağından kinaî ve sembolik bir manayı ifade eder. Aksi takdirde bu bilgiler onun okur yazar olmadığını, medreseden habersiz olduğunu dile getiriyor değildir.

Hakîkatün ma'nîsin şerh ile bilmediler

Erenler bu dirligi riyâ dirilmediler

Hakîkat bir denizdür şerî’atdur gemisi

Çoklar gemiden çıkup denize talmadılar

Bular geldi tapuya şerî‘ at tutdı turur

İçerü girübeni ne varın bilmediler

Şerî’at oglanları bahis da'vî kılurlar

Hakîkat erenleri da'vîye kalmadılar

Dört kitâb1 şerh iden 'âsîdür hakîkatde

Zirâ tefsîr okuyup ma'nîsin bilmediler ${ }^{53}$

Yunus kendilerinin Tevrat, Zebur, İncil ve Kur'an gibi dört kitabın özüne vakıf olduklarını, dört kitabın mana, maksat ve mesajının elif harfinde belli olduğunu, yani dört kitabın gayesinin marifetullah ilmi ve dürüstlük olduğunu, dolayısıyla diğer alfabe harflerinden ibaret olan zahiri ilimleri kendilerine söyletme çabası içine girmelerine gerek olmadığını, kendilerinin bu zahiri ilimler yolunda şaşırıp azacaklarını ifade etmiştir. O bakımdan Yunus, şeriat ehlinin yani fakihlerin, müderrislerin, zahiri ulemanın (ulemayı rüsum), Hakikat deryasında yüzenlerin niçin yollarını kesmeye çalıştıklarını bir türlü anlayamamaktadır. Yunus'un

51 Faruk Kadri Timurtaş, Yunus Emre Divam (İstanbul: Tercüman Gazetesi, ts.), 32.

52 Köprülü, Türk Edebiyatinda İlk Mutasavvrflar, 271.

53 Tatçı, Yûnus Emre Dî̀ân, 31. 
aşağıdaki bu dizelerinden Tanrıyı bilme, bulma ve ona varma yol ve yöntemlerinin farklı olduğu medrese ile tekke arasinda kadim zamanlardan beri devam eden sürtüşmenin 13. yüzyll Anadolu'sunda da devam ettiği anlaş1liyor.

Dört kitabın okudum, tahsil ettim bitirdim

Ne hacet kim, karayı ak üstüne yazarım

Dört kitabın mânisi, bellidir bir elifte

Be dedirmegil bana, ben bu yolda azarım

Yetmiş iki millete suçum budur hak dedim

Korku hiyanetedir ya ben niçin kızarım

Şeriat oğlanları niçin yol keser bana

Hakikat deryasında bahrî oldum yüzerim ${ }^{54}$

\section{SONUÇ}

$\mathrm{Bu}$ çalışmada dervişlerin, fakih, molla ve müderrislerin, kendilerini, iç dünyalarını ve davranışlarını kötülüklerden arındırmaksızın namaz, oruç, hac, zekât, kurban; tesbih, seccade, hırka, taç, zikir vb. salt zahiri düzeyde kalan şekilsel dindarlıklarına, Yunus Emre tarafindan yöneltilen eleştiriler ele alınmıştır. Doküman analizi yönteminin kullanıldığ 1 bu araştırma neticesinde, Yunus Emre'nin ahlaktan ve temel insanlık değerlerinden yoksun dindarlık eleştirisi, başka bir deyişle bağlı olduğu amaç, ülkü açısından içinde bulunduğu Müslüman/sufi toplumun ve zahir şeriat ehlinin şekil ve görüntüde kalan dini tutum ve tavırlarına, din ve tanrı anlaysşlarına yönelik 13. ve 14. yüz yıla has bir öz eleştiri prototipi ortaya konulmuştur. Genel olarak Müslümanların, özelde ise şeyh, derviş, müderris ve fakihlerin, dışını İslamlaştırmış ancak içini/özünü, gönlünü ve halini bir türlü Müslüman edememiş, sadece tesbih ve seccadede, taç, hırka ve hüllede, sarık ve cübbede kalan dindarlık anlayışlarını yeniden gözden geçirip düşünmelerine firsat vereceğini düşünmekteyiz. Aynı şekilde bu araştırmanın, Türk İslam geleneğinde araştırmacılanı bekleyen bu türden daha nice öz bakış ve

54 Toprak, Yunus Emre Divanı, 97; Tatçı, Yûnus Emre Dîvân, 136. 
eleştirilerin, otokritik düşüncenin Kütüphanelerin tozlu raflarından gün yüzüne çıkarılmasına ve araştırılmasına ön ayak olacağını ümit etmekteyiz. 


\section{KAYNAKÇA}

Başgöz, İlhan. Yunus Emre. İzmir: Cumhuriyet Dünya Klasikleri, 1999.

Çubukçu, İbrahim Agâh. "Yunus Emre ve din felsefesi". Ankara Üniversitesi İlahiyat Fakültesi Dergisi XIX (1973), 1-15.

Eyuboğlu, Sabahattin. Yunus Emre. İstanbul: Cem Yayınevi, 1971.

Gölpınarlı, Abdulbaki. Yunus Emre Hayat,, Sanatı ve Şïrleri. İstanbul: Varlık Yayınevi, 8. Basım, 1975.

Gölpınarl1, Abdulbaki. Yunus Emre Hayatı ve Bütün Şïrleri. İstanbul: Türkiye İşbankası Kültür Yayınları, 2006.

Halman, Talat. A'dan Z'ye Yunus Emre. İstanbul: Yap1 Kredi Yayınlar1, 2003.

Köprülü, Fuad. Türk Edebiyatinda İlk. Mutasavvflar. Ankara: Türk Tarih Kurumu Basımevi, 3. Basım 1976.

Kurnaz, Cemâl. "Yunus Emre'de Tenkit". Türk Kültürü Araştırmalar. XXIX, 1-2, (1991), 257-263.

Özçelik, Mustafa. Biæ̧im Yunus. Ankara: T.C Eskişehir Valiliği, 1. Basım 2010.

Öztelli, Cahit. Yunus Emre Yaşamı ve Bütün Şiirleri. İstanbul: Özgür Yayın Dağıtım. 4. Basım 1992.

Taş, İsmail, "Yesevi ve Yunus'ta Sufi Eleştirisi”, I. Ulusal Yunus Emre Sempozyumu, Karaman: Karaman İl Kültür ve Turizm Müdürlügü Kültür Yayınları, 2010.

Tatç1, Mustfa. Yûnus Emre Dîvân. Ankara: T. C. Kültür ve Turizm Bakanllğı Kütüphaneler ve Yayımlar Genel Müdürlügü, ts.

Timurtaş, Faruk Kadri. Yunus Emre Divamı. İstanbul: Tercüman Gazetesi, ts.

Toprak, Burhan. Yunus Emre Divanı. İstanbul: Odunpazar1 Belediyesi Yayınları. 3. Basım, 2006.

Yunus Emre. Nasihatler Kitabı (Risâletu'n-Nushiye). Eskişehir: Türk Dünyas1 Kültür Başkenti Ajans1, 2013. 